\title{
KERAGAMAN JENIS TUMBUHAN BAWAH PADA TEGAKAN KELAPA SAWIT DAN POTENSINYA SEBAGAI PAKAN TERNAK SAPI POTONG (KASUS DI DESA KUNGKAI BARU KABUPATEN SELUMA)
}

\author{
Jhon Firison $^{1)}$, Wiryono ${ }^{2)}$, Bieng Brata ${ }^{3)}$ \\ ${ }^{1)}$ Program Pascasarjana Pengelolaan Sumber Daya Alam dan Lingkungan, Fakultas \\ Pertanian, Universitas Bengkulu \\ ${ }^{1)}$ Balai Pengkajian Teknologi Pertanian Balitbangtan Bengkulu Kota Bengkulu \\ ${ }^{2)}$ Jurusan Kehutanan Fakultas Pertanian Universitas Bengkulu \\ ${ }^{3)}$ Jurusan Peternakan Fakultas Pertanian Universitas Bengkulu
}

\begin{abstract}
ABSTRAK
Tumbuhan bawah adalah salah satu lapisan pada kawasan hutan yang terletak di bawah kanopi pohon yang terdiri atas tumbuhan berkayu, semak, tanaman merambat, dan herba Penelitian berjudul "Identifikasi Jenis Tumbuhan Bawah pada Tegakan Kelapa Sawit dan Potensinya sebagai Pakan Ternak Sapi Potong” telah dilaksanakan pada bulan Juli sampai dengan September 2018 di Desa Kungkai Baru, Kecamatan Air Periukan, Kabupaten Seluma. Tujuan penelitian yaitu: (1) mengidentifikasi keragaman jenis tumbuhan bawah pada tegakan kelapa sawit umur 2, 7, dan 15 tahun, (2) menghitung dominasi jenis tumbuhan bawah, dan (3) menentukan daya tampung ternak sapi potong pada berbagai umur tegakan kelapa sawit. Pengumpulan data dilakukan dengan cara: (1) sampling tumbuhan bawah dengan kuadran ukuran 1 x 1 meter pada 26 plot pengamatan yang dilengkapi dengan dokumentasi foto, (2) identifikasi jenis tumbuhan bawah menggunakan buku panduan identifikasi dan situs internet, (3) penghitungan biomassa berdasarkan hasil analisis laboratorium, dan (4) menentukan tingkat kesukaan ternak sapi potong (palatabilitas) terhadap tumbuhan bawah berdasarkan hasil wawancara dengan 4 orang peternak. Analisis data dilakukan secara deskriptif. Hasil penelitian menyimpulkan bahwa: (1) ditemukan 53 jenis tumbuhan bawah pada seluruh tegakan kelapa sawit yang terdiri atas 46 genus dan 29 famili; (2) famili Poaceae merupakan tumbuhan bawah penting pada seluruh umur tegakan kelapa sawit; (3) daya tampung tumbuhan bawah pada tegakan kelapa sawit berumur 2, 7, dan 15 tahun semakin menurun dengan bertambahnya umur tegakan, berturut-turut 2,01, 1,37, dan 0,76 ST/hektar/tahun.
\end{abstract}

Kata kunci : tumbuhan bawah, kelapa sawit, daya tampung, sapi potong

\section{PENDAHULUAN}

\begin{abstract}
Merujuk pada definisi yang tertuang dalam UU No 4 tahun 2009 tentang Pertambangan Mineral dan Batubara, pascatambang diartikan sebagai kegiatan setelah akhir sebagian atau seluruh kegiatan usaha pertambangan untuk memulihkan fungsi lingkungan dan fungsi sosial. Untuk mewujudkan pembangunan berkelanjutan, kegiatan usaha pertambangan harus dilaksanakan dengan memperhatikan prinsip lingkungan hidup, transparansi dan partisipasi
\end{abstract}

masyarakat. Prinsip pengelolaan lingkungan hidup meliputi perlindungan terhadap kualitas air permukaan, air tanah, air laut, dan udara sesuai dengan standar baku mutu lingkungan hidup dan ketentuan peraturan perundang-undangan.

Reklamasi adalah usaha memperbaiki (memulihkan kembali) lahan yang rusak sebagai akibat kegiatan usaha pertambangan, agar dapat berfungsi secara optimal sesuai dengan kemampuannya (Latifah, 2003). Penanganan tanah zona 
pengakaran perlu dilakukan pada waktu pengupasan tanah penutup pada saat memulai kegiatan penambangan. Tanah penutup dikupas, dipindahkan dan ditimbun disekitar area pit yang dibuka hal ini dilakukan untuk digunakan untuk menimbun kembali lahan bekas tambang tersebut.

Tumbuhan bawah adalah suatu tipe vegetasi dasar yang terdapat di bawah lahan hutan yang meliputi semak dan herba (Wiryono, 2009). Tumbuhan bawah pada di bawah tegakan kelapa sawit sering dianggap sebagai gulma yang merugikan petani sehingga perlu dikendalikan. Padahal tumbuhan bawah di bawah tegakan kelapa sawit dapat diintegrasikan dengan ternak sapi potong dengan pola pemeliharaan ternak secara semi intensif dan ekstensif.

Sapi potong merupakan komoditas ternak yang penting bagi petani di pedesaan. Pentingnya peranan sapi potong tersebut dikarenakan jenis ternak sapi potong mempunyai fungsi ekonomi bagi petani. Umumnya petani memelihara ternak sapi potong untuk dijadikan sebagai tabungan yang dapat dimanfaatkan sewaktu-waktu ketika membutuhkan biaya atau memerlukan uang dalam jumlah yang cukup besar. Selain itu ternak sapi potong juga dapat dimanfaatkan sebagai ternak konsumsi ketika ada perayaan atau hajatan serta dimanfaatkan sebagai tenaga kerja dalam kegiatan usahatani seperti membajak sawah dan mengangkut hasil pertanian (Firison dan Ishak, 2017; Ishak et al., 2017).

Penggembalaan ternak sapi potong di bawah tegakan kelapa sawit akan bermanfaat bagi tanaman kelapa sawit. Ternak sapi yang mengkonsumsi tumbuhan bawah dapat mengurangi biaya penyiangan gulma, mengurangi biaya pemupukan karena adanya kotoran ternak (feses dan urin) dari sapi yang digembalakan. Gunawan dan Talib (2014) mengutip pendapat dari berbagai sumber menulis bahwa feses yang dihasilkan dari setiap ekor ternak sapi dewasa sekitar 4 ton per tahun yang mampu menghasilkan dua ton pupuk organik dan urin sebanyak 5.500 liter per tahun.

Direktorat Perbibitan Ternak Kementan (2014) menyatakan bahwa kebutuhan pakan hijauan segar ternak sapi potong adalah sebesar 10 persen dari bobot tubuh. Umumnya peternak memelihara jenis sapi Bali karena memiliki keunggulan yaitu potensi genetiknya tinggi dan mudah beradaptasi dengan lingkungan dan tatalaksana pemeliharaan sederhana. Sapi Bali juga tidak selektif dalam memilih pakan dan mampu memberikan respons pertumbuhan yang baik bila diberi pakan dengan kualitas rendah.

Mathius (2008) memperkirakan bahwa kebutuhan konsumsi bahan kering untuk pakan sapi potong sebanyak 4\% dari bobot hidup. Bobot hidup sapi Bali di atas $250 \mathrm{~kg} / \mathrm{ekor}$ sudah jarang ditemukan. Oleh karena itu, kebutuhan pakan untuk sapi Bali diasumsikan $10 \quad \mathrm{~kg}$ bahan kering/ekor/hari. Jumlah ini merupakan kebutuhan pakan untuk satu satuan ternak (ST) untuk menghitung daya tampung ternak pada suatu lahan penggembalaan.

Daya tampung ternak merupakan angka yang menunjukkan jumlah ternak yang dapat digembalakan dalam luasan tertentu dan dalam jangka waktu tertentu tanpa mengakibatkan kerusakan lokasi penggembalian dan pertumbuhan ternak (Susetyo, 1980 dalam Farizaldi, 2011). Daya tampung ternak pada perkebunan kelapa sawit tergantung antara lain oleh umur tanaman kelapa sawit dan komposisi tumbuhan bawah (Purwantari et al., 2015).

Penelitian tentang ekologi tumbuhan bawah di bawah tegakan kelapa sawit yang dihubungkan dengan daya tampung ternak menjadi suatu hal yang menarik. Hal ini karena hasil-hasil penelitian sebelumnya lebih menekankan pada aspek ekologis tumbuhan bawah atau daya tampung ternaknya saja. Oleh karena itu, penelitian ini bertujuan untuk: (1) mengidentifikasi keragaman jenis tumbuhan bawah pada tegakan kelapa sawit umur 2, 7, dan 15 tahun, (2) 
menghitung dominasi jenis tumbuhan bawah, dan (3) menentukan daya tampung ternak sapi potong pada berbagai umur tegakan kelapa sawit.

\section{METODE PENELITIAN}

Penelitian dilakukan pada bulan Juli sampai dengan September 2018 di Desa Kungkai Baru, Kecamatan Air Periukan, Kabupaten Seluma pada perkebunan kelapa sawit rakyat umur 2, 7, dan 15 tahun. Pengambilan sampel tumbuhan bawah menggunakan metode kuadrat 1 x 1 meter sebanyak 26 plot pengamatan. Identifikasi jenis dilakukan di lapangan menggunakan buku panduan identifikasi dan situs internet. Penentuan dominasi jenis dilakukan dengan menghitung Indeks Nilai Penting (INP) (Wiryono, 2009).

\section{HASIL DAN PEMBAHASAN}

\section{Identifikasi Jenis Tumbuhan Bawah}

Jenis-jenis tumbuhan bawah pada tegakan kelapa sawit di Desa Kungkai Baru sangatlah beragam. Dari hasil identifikasi pada tiga kebun lokasi penelitian ditemukan jumlah keseluruhan jenis tumbuhan bawah pada tegakan kelapa sawit di Desa Kungkai Baru sebanyak 53 jenis yang digolongkan ke dalam 46 genus dan 29 famili (Tabel 1). Jenis tumbuhan bawah paling banyak ditemukan di bawah tegakan kelapa sawit berumur 2 tahun (32 jenis), selanjutnya pada umur 7 tahun (28 jenis), dan terakhir pada umur 15 tahun (19 jenis). Sebaran spesies, genus, dan famili tumbuhan bawah ditampilkan pada Gambar 1.

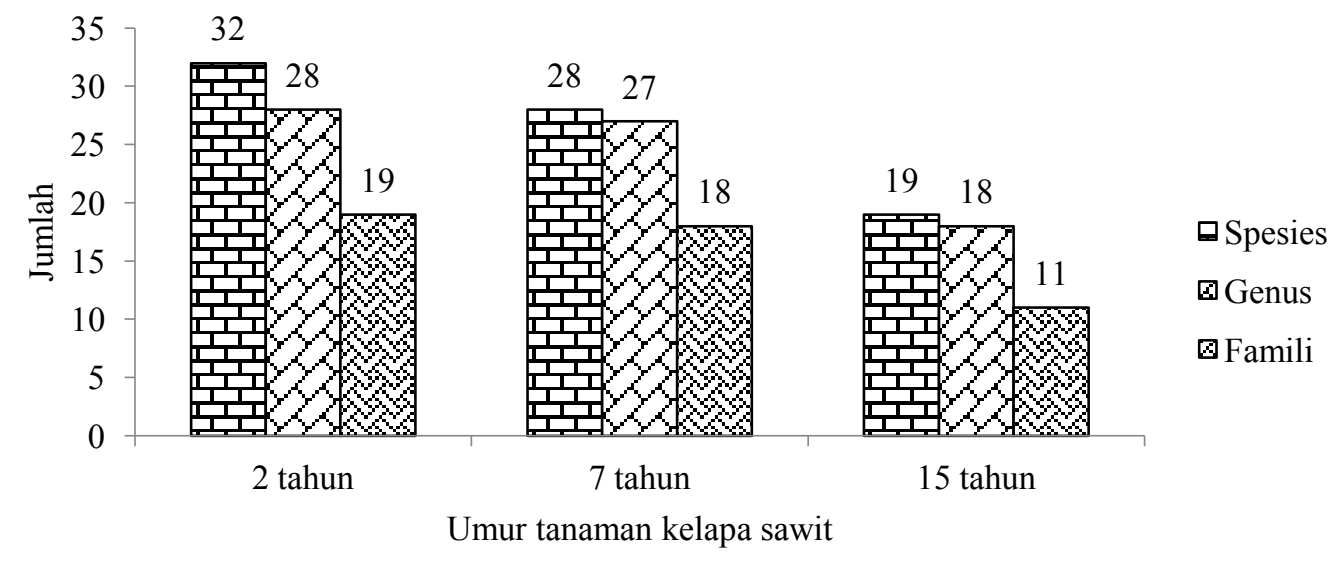

Gambar 1. Jumlah spesies, genus, dan famili tumbuhan bawah yang ditemukan di bawah tegakan kelapa sawit umur 2, 7, dan 15 tahun.

Gambar 1 menunjukkan bahwa jumlah jenis tumbuhan bawah yang ditemukan berbanding terbalik (berkorelasi negatif) dengan umur tanaman. Semakin tua umur tanaman kelapa sawit, semakin sedikit jumlah jenis tumbuhan bawah yang ditemukan di bawah tegakan kelapa sawit. Hal ini karena pengaruh tutupan kanopi yang semakin luas sehingga menghambat proses fotosintesis dan pertumbuhan tanaman. Menurut Sastroutomo (1990 dalam Ersyad et al., 2017), cahaya matahari merupakan faktor penentu pertumbuhan tanaman. Kurangnya intensitas cahaya akibat penutupan kanopi kelapa sawit akan menghambat perkembangan tumbuhan bawah. Dengan kata lain, jumlah jenis suatu komunitas tumbuhan berkorelasi negatif dengan naungan ( $\operatorname{Rad}$ et al., 2009). 
Tabel 1. Hasil identifikasi jenis tumbuhan bawah berdasarkan umur tegakan kelapa sawit.

\begin{tabular}{|c|c|c|c|c|c|}
\hline \multirow{2}{*}{ No. } & \multirow{2}{*}{ Nama Jenis } & \multirow{2}{*}{ Nama Famili } & \multicolumn{3}{|c|}{ Umur tanaman kelapa sawit } \\
\hline & & & 2 tahun & 7 tahun & 15 tahun \\
\hline 1. & Acroceras munroanum & Poaceae & $\sqrt{ }$ & $\sqrt{ }$ & $\sqrt{ }$ \\
\hline 2. & Ageratum conyzoides & Asteraceae & $\sqrt{ }$ & $\sqrt{ }$ & $\sqrt{ }$ \\
\hline 3. & Asplenium longissimum & Aspleniaceae & & $\sqrt{ }$ & $\sqrt{ }$ \\
\hline 4. & Asystasia gangetica & Acanthaceae & & $\sqrt{ }$ & $\sqrt{ }$ \\
\hline 5. & Axonopus compressus & Poacea & $\sqrt{ }$ & $\sqrt{ }$ & $\sqrt{ }$ \\
\hline 6. & Centotheca lappacea & Poacea & & $\sqrt{ }$ & \\
\hline 7. & Ceratopteris thalictroides & Pteridaceae & $\sqrt{ }$ & & \\
\hline 8. & Clidemia hirta & Melastomataceae & & $\sqrt{ }$ & \\
\hline 9. & Cyanthillium cinereum & Asteraceae & $\sqrt{ }$ & & \\
\hline 10. & Cyperus rotundus & Cyperaceae & $\sqrt{ }$ & $\sqrt{ }$ & \\
\hline 11. & Desmodium heterophyllum & Fabaceae & $\sqrt{ }$ & $\sqrt{ }$ & \\
\hline 12. & Dicranopteris linearis & Gleicheniaceae & & & $\sqrt{ }$ \\
\hline 13. & Elaeis guineensis & Arecaceae & $\sqrt{ }$ & $\sqrt{ }$ & \\
\hline 14. & Eragrostis tenella & Poacea & & & $\sqrt{ }$ \\
\hline 15. & Eriocaulon gomphrenoides & Eriocaulaceae & $\sqrt{ }$ & & \\
\hline 16. & Euphorbia hirta & Euphorbiaceae & $\sqrt{ }$ & & \\
\hline 17. & Hyptis capitata & Lamiaceae & & & $\sqrt{ }$ \\
\hline 18. & Ischaemum muticum & Poacea & & & $\sqrt{ }$ \\
\hline 19. & Kyllinga brevifolia & Cyperaceae & $\sqrt{ }$ & $\sqrt{ }$ & \\
\hline 20. & Lindernia ciliata & Linderniaceae & $\sqrt{ }$ & & \\
\hline 21. & Lindernia crustacea & Linderniaceae & $\sqrt{ }$ & & \\
\hline 22. & Lindernia dubia & Linderniaceae & $\sqrt{ }$ & $\sqrt{ }$ & $\sqrt{ }$ \\
\hline 23. & Lindsaea divergens & Dennstaedtiaceae & & $\sqrt{ }$ & \\
\hline 24. & Ludwigia hyssopifolia & Onagraceae & $\sqrt{ }$ & & \\
\hline 25. & Lycopodiella cernua & Lycopodiaceae & $\sqrt{ }$ & $\sqrt{ }$ & \\
\hline 26. & Lygodium flexuosum & Schizaeaceae & & $\sqrt{ }$ & \\
\hline 27. & Lygodium microphyllum & Schizaeaceae & & $\sqrt{ }$ & $\sqrt{ }$ \\
\hline 28. & Lygodium palmatum & Schizaeaceae & $\sqrt{ }$ & & \\
\hline 29. & Mecardonia procumbens & Plantaginaceae & $\sqrt{ }$ & & \\
\hline 30. & Melastoma malabathricum & Melastomataceae & & $\sqrt{ }$ & \\
\hline 31. & Mikania micrantha & Asteraceae & & & $\sqrt{ }$ \\
\hline 32. & Mitracarpus hirtus & Rubiaceae & $\sqrt{ }$ & & \\
\hline 33. & Murdannia spirata & Commelinaceae & & $\sqrt{ }$ & \\
\hline 34. & Oldenlandia auricularia & Rubiaceae & $\sqrt{ }$ & $\sqrt{ }$ & \\
\hline 35. & Paspalum conjugatum & Poacea & & & $\sqrt{ }$ \\
\hline 36. & Paspalum scrobiculatum & Poacea & $\sqrt{ }$ & $\sqrt{ }$ & $\sqrt{ }$ \\
\hline 37. & Peperomia pellucida & Piperaceae & & $\sqrt{ }$ & \\
\hline 38. & Phyllanthus debilis & Phyllanthaceae & $\sqrt{ }$ & $\sqrt{ }$ & \\
\hline 39. & Phyllanthus urinaria & Phyllanthaceae & $\sqrt{ }$ & & \\
\hline 40. & Pityrogramma calomelanos & Adiantaceae & & $\sqrt{ }$ & $\sqrt{ }$ \\
\hline 41. & Plectranthus monostachyus & Lamiaceae & & $\sqrt{ }$ & \\
\hline 42. & Polygala paniculata & Polygalaceae & $\sqrt{ }$ & & \\
\hline 43. & Pouzolzia zeylanica & Urticaceae & $\sqrt{ }$ & & $\sqrt{ }$ \\
\hline 44. & Praxelis clematidea & Asteraceae & $\sqrt{ }$ & & \\
\hline 45. & Scleria bancana & Cyperaceae & $\sqrt{ }$ & & \\
\hline 46. & Scoparia dulcis & Scrophulariaceae & $\sqrt{ }$ & & \\
\hline 47. & Spermacoce alata & Rubiaceae & $\sqrt{ }$ & $\sqrt{ }$ & \\
\hline 48. & Spermacoce articularis & Rubiaceae & $\sqrt{ }$ & & \\
\hline 49. & Stachytarpheta jamaicensis & Verbenaceae & & $\sqrt{ }$ & $\sqrt{ }$ \\
\hline 50. & Struchium sparganophorum & Asteraceae & $\sqrt{ }$ & $\sqrt{ }$ & $\sqrt{ }$ \\
\hline 51. & Synedrella nudiflora & Asteraceae & $\sqrt{ }$ & & \\
\hline 52. & Tectaria crenata & Tectariaceae & & $\sqrt{ }$ & \\
\hline 53. & Vitex negundo & Lamiaceae & & & $\sqrt{ }$ \\
\hline & Jumlah jenis & & 32 & 28 & 19 \\
\hline & Jumlah genus & & 28 & 27 & 18 \\
\hline & Jumlah famili & & 18 & 20 & 11 \\
\hline
\end{tabular}


Jenis tumbuhan bawah dari famili Poaceae (suku padi-padian) paling banyak ditemukan pada tegakan kelapa sawit yaitu sebanyak 7 jenis (Gambar 2). Terdapat 6 jenis tumbuhan bawah yang ditemukan pada seluruh umur tegakan yaitu Acroceras munroanum, Ageratum conyzoides, Axonopus compressus, Lindernia dubia, Paspalum scrobiculatum, dan Struchium sparganophorum. Dari 6 jenis tumbuhan bawah tersebut, 3 jenis diantaranya termasuk ke dalam famili Poaceae yaitu $A$. munroanum, $A$. compressus, dan P. scrobiculatum.

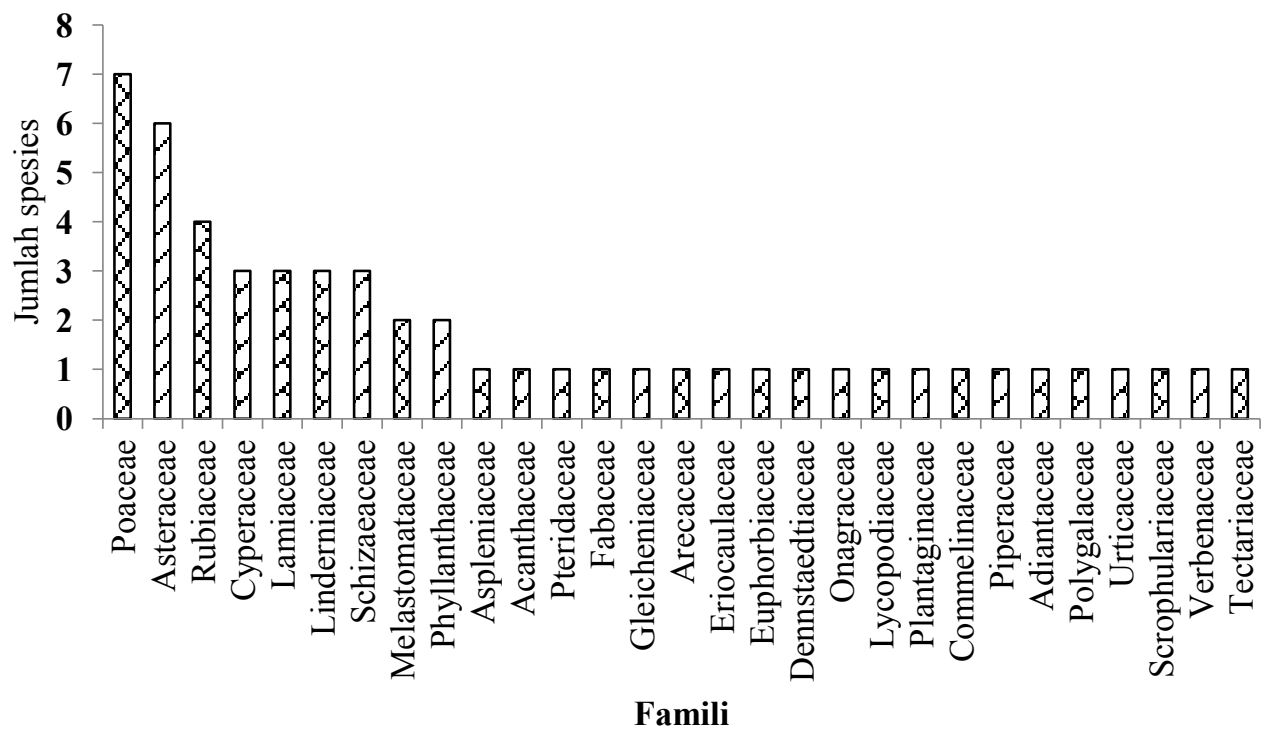

Gambar 2. Famili dan jumlah spesies tumbuhan bawah yang teridentifikasi

Poaceae adalah famili tumbuhan yang paling banyak ditemukan di perkebunan kelapa sawit karena bersifat adaptif dengan sistem perakaran sehingga mampu menyerap nutrisi dan air dengan baik, serta memiliki kemampuan reproduksi secara generatif yang tinggi (Arsyad et al., 2011). Menurut Campbell (2018), famili Poaceae termasuk tanaman berbunga monokotil dari Ordo Poales. Famili Poacea sangat penting artinya karena merupakan sumber pangan yang dibudidayakan di seluruh dunia. Rumputrumputan dari famili Poaceae mendominasi $24 \%$ jenis vegetasi di alam. Jumlah famili Poaceae di alam diperkirakan sebanyak 500 genus dan 8.000 spesies.

\section{Indeks Nilai Penting (INP) Spesies Tumbuhan Bawah}

INP adalah parameter kuantitatif yang dapat dipakai untuk menyatakan tingkat dominansi (tingkat penguasaan) spesies-spesies dalam suatu komunitas tumbuhan. Spesies yang dominan dalam suatu komunitas tumbuhan akan memiliki INP yang tinggi (Indriyanto, 2012) dan merupakan salah satu parameter yang menunjukkan peranan jenis tumbuhan tersebut dalam komunitasnya (Ismani et al., 2015).

Tumbuhan dari famili Poaceae merupakan jenis-jenis tumbuhan yang dominan. Pada tegakan kelapa sawit berumur 2 dan 7 tahun, jenis Acroceras munroanum memiliki nilai INP tertinggi yaitu masing-masing $31,21 \%$ dan $16,54 \%$, sedangkan Paspalum scrobiculatum mendominasi pada tegakan berumur 15 tahun dengan nilai INP 19,72\% (Tabel 2). 
Tabel 2. Nilai INP dominan (\%) lima jenis tumbuhan bawah pada tegakan kelapa sawit umur

\begin{tabular}{|c|c|c|c|c|c|}
\hline \multicolumn{2}{|l|}{ Umur 2 tahun } & \multicolumn{2}{|l|}{ Umur 7 tahun } & \multicolumn{2}{|l|}{ Umur 15 tahun } \\
\hline Nama Jenis & $\%$ & Nama Jenis & $\%$ & Nama Jenis & $\%$ \\
\hline Acroceras & 31,21 & Acroceras & 16,5 & Paspalum & 19,7 \\
\hline munroanum & & munroanum & 4 & scrobiculatum & 2 \\
\hline Kyllinga & 8,27 & Paspalum & 16,3 & Asystasia gangetica & 14,4 \\
\hline brevifolia & & scrobiculatum & 1 & & 2 \\
\hline Lycopodiella & 4,88 & Axonopus compressus & 9,66 & Dicranopteris & 11,5 \\
\hline cernua & & & & linearis & 4 \\
\hline $\begin{array}{l}\text { Cyanthillium } \\
\text { cinereum }\end{array}$ & 4,48 & $\begin{array}{l}\text { Melastoma } \\
\text { malabathricum }\end{array}$ & 7,15 & Ageratum conyzoides & 7,39 \\
\hline Lindernia dubia & 4,37 & Kyllinga brevifolia & 6,97 & $\begin{array}{l}\text { Acroceras } \\
\text { munroanum }\end{array}$ & 7,04 \\
\hline
\end{tabular}

Tabel 2 menunjukkan bahwa nilai INP Acroceras munroanum semakin menurun dengan bertambahnya umur tegakan, sementara nilai INP Paspalum scrobiculatum semakin meningkat dengan bertambahnya umur tegakan. Hal ini berarti bahwa famili Poaceae memiliki adaptasi yang berbeda-beda terhadap naungan. $A$. munroanum dan $P$. scrobiculatum termasuk jenis rumput berdaun sempit. Dari berbagai hasil penelitian, ditunjukkan bahwa tumbuhan bawah berdaun sempit dominan ditemukan di bawah tegakan kelapa sawit (Syahputra et al., 2011; Prasetyo dan Zaman, 2016; Hutasoit et al., 2017; Simangunsong et al., 2018).

Acroceras munroanum mampu beradaptasi dengan baik pada berbagai ekosistem. Hal ini dibuktikan dengan hasil penelitian Azhari (2017) yang menemukan bahwa nilai INP tumbuhan bawah ini mencapai $93,05 \%$ di bawah tegakan aren di Kabupaten Rejang Lebong pada ketinggian lebih dari $1.000 \mathrm{mdpl}$.

Paspalum scrobiculatum berasal dari Afrika Barat dan terutama menyebar ke India dan Asia Tenggara (Filipina, Indonesia, Vietnam, dan Thailand). Spesies ini toleran pada tanah marjinal ketika tanaman lain tidak mampu beradaptasi dengan baik, serta mampu menghasilkan biji $450-900 \mathrm{~kg}$ per hektar yang dimanfaatkan oleh para petani subsisten di Afrika sebagai bahan makanan. Tanaman ini juga dimanfaatkan sebagai pakan ternak, daunnya berkhasiat sebagai antiseptik untuk pengobatan kulit, keracunan, narkotika, luka, dan diabetes (Kusuma dan Suryani, 2017).

\section{Daya Tampung Ternak Sapi pada Tegakan Kelapa Sawit}

Ketika mengamati secara selintas ternak sapi yang sedang merumput pada tegakan kelapa sawit, terkesan ternak sapi mengkonsumsi semua jenis tumbuhan bawah. Namun demikian, ternak sapi lebih menyukai lokasi yang lapang dan bukan di semak-semak. Hal ini mengisyaratkan bahwa tidak seluruh tumbuhan bawah pada tegakan kelapa sawit dikonsumsi ternak sapi. Hal ini terkonfirmasi berdasarkan hasil wawancara dengan petani bahwa dari 53 jenis tumbuhan bawah, hanya 11 jenis yang dimanfaatkan sebagai pakan ternak sapi potong. Biomassa tumbuhan bawah setiap jenis yang dikonsumsi ternak disajikan pada Tabel 3.

Perhitungan daya tampung ternak berdasarkan biomassa tumbuhan bawah disajikan pada Tabel 4 yang menunjukkan bahwa kebutuhan pakan ternak sapi potong per tahun sebesar $3.650 \mathrm{~kg}$ bahan kering pakan. Biomassa pakan tumbuhan bawah pada masing-masing kebun berbeda menurut umur kelapa sawit, sehingga daya tampungnya juga berbeda. Pada umur tanaman kelapa sawit 2 tahun, biomassa tumbuhan bawah yang menjadi hijauan pakan ternak sebesar $7.704,2 \mathrm{~kg} / \mathrm{ha}$ yang mampu menanmpung 2,01 satuan ternak 
(ST)/ha/tahun. Pada umur kebun kelapa sawit 7 tahun, biomassa tumbuhan bawah menurun menjadi $5.267 \mathrm{~kg} / \mathrm{ha}$ dan daya tampung ternaknya juga menurun menjadi 1,37 ST/ha/tahun. Biomassa tumbuhan bawah terkecil diperoleh pada umur tanaman kelapa sawit 15 tahun yaitu
2.903,7 kg/ha yang hanya mampu menampung $0,76 \mathrm{ST} / \mathrm{ha} /$ tahun. Hal ini menunjukkan bahwa jumlah satuan ternak pada perkebunan kelapa sawit semakin menurun dengan bertambahnya umur tanaman.

Tabel 3. Biomassa (bahan kering) tumbuhan bawah yang dimanfaatkan sebagai pakan ternak

\begin{tabular}{|c|c|c|c|c|}
\hline \multirow{2}{*}{ No. } & \multirow{2}{*}{ Nama Jenis } & \multicolumn{3}{|c|}{ Bahan kering tumbuhan bawah (gram) } \\
\hline & & 2 tahun & 7 tahun & 15 tahun \\
\hline 1. & Acroceras munroanum & 581 & 195,3 & 52,2 \\
\hline 2. & Axonopus compressus & 10 & 88,7 & 12,9 \\
\hline 3. & Centotheca lappacea & - & 1,47 & - \\
\hline 4. & Cyperus rotundus & 12,4 & 1,99 & - \\
\hline 5. & Elaeis guineensis & 0,6 & 0,43 & - \\
\hline 6. & Eragrostis tenella & - & - & 12 \\
\hline 7. & Ischaemum muticum & - & - & 23 \\
\hline 8. & Kyllinga brevifolia & 120,52 & 38,41 & - \\
\hline 9. & Mikania micrantha & - & - & 0,97 \\
\hline 10. & Paspalum conjugatum & - & - & 20 \\
\hline 11. & Paspalum scrobiculatum & 45,9 & 200,4 & 169,3 \\
\hline & Total bahan kering & 770,42 & 526,7 & 290,37 \\
\hline
\end{tabular}

Tabel 4. Daya tampung ternak pada tegakan kelapa sawit umur 2, 7, dan 15 tahun.

\begin{tabular}{|c|c|c|c|c|}
\hline \multirow[t]{2}{*}{ No. } & \multirow[t]{2}{*}{ Uraian } & \multicolumn{3}{|c|}{ Umur kebun kelapa sawit } \\
\hline & & 2 tahun & 7 tahun & 15 tahun \\
\hline 1. & Bahan kering (kg) & 0,77042 & 0,5267 & 0,29037 \\
\hline 2. & Bahan kering per hektar $(\mathrm{kg})$ & $7.704,2$ & 5.267 & $2.903,7$ \\
\hline 3. & $\begin{array}{l}\text { Kebutuhan pakan ternak/ekor/hari } \\
\text { (kg)/ST }\end{array}$ & 10 & 10 & 10 \\
\hline 4. & Kebutuhan pakan ternak per tahun $(\mathrm{kg})$ & 3.650 & 3.650 & 3.650 \\
\hline 5. & Daya tampung ternak (ST/hektar/tahun) & 2,01 & 1,37 & 0,76 \\
\hline
\end{tabular}

Daya tampung ternak sapi potong pada tegakan kelapa sawit yang disajikan pada Tabel 4 relatif sama dengan hasilhasil penelitian lainnya, baik yang dilakukan pada perkebunan kelapa sawit swasta maupun perkebunan rakyat. Perbandingan hasil penelitian lapangan dengan beberapa hasil penelitian sebelumnya ditampilkan pada Tabel 5. 
Tabel 5. Perbandingan hasil penelitian lapangan dengan hasil-hasil penelitian lainnya tentang daya tampung ternak sapi potong pada tegakan kelapa sawit.

\begin{tabular}{|c|c|c|c|c|}
\hline No. & Hasil penelitian & Lokasi kebun & $\begin{array}{l}\text { Umur tegakan } \\
\text { (tahun) }\end{array}$ & $\begin{array}{l}\text { Daya tampung } \\
\text { (ST/ha/tahun) }\end{array}$ \\
\hline 1. & $\begin{array}{l}\text { Chen dan Dahlan (1995 } \\
\text { dalam Batubara, 2003) }\end{array}$ & $\begin{array}{l}\text { Perkebunan } \\
\text { swasta }\end{array}$ & - & $0,3-3$ \\
\hline \multirow[t]{3}{*}{2.} & \multirow{3}{*}{$\begin{array}{l}\text { Wan Mohammad et al. (1997 } \\
\text { dalam Daru et al., 2014) }\end{array}$} & \multirow{3}{*}{$\begin{array}{l}\text { Perkebunan } \\
\text { swasta }\end{array}$} & $1-2$ & 3 \\
\hline & & & $2-3$ & 2 \\
\hline & & & 5 & 1 \\
\hline \multirow{2}{*}{\multicolumn{2}{|c|}{ 3. Daru et al. (2014) }} & \multirow{2}{*}{$\begin{array}{l}\text { Perkebunan } \\
\text { rakyat }\end{array}$} & 3 & 1,44 \\
\hline & & & 6 & 0,71 \\
\hline \multirow{3}{*}{\multicolumn{2}{|c|}{ 4. Penelitian lapangan }} & \multirow{3}{*}{$\begin{array}{l}\text { Perkebunan } \\
\text { rakyat }\end{array}$} & 2 & 2,01 \\
\hline & & & 7 & 1,37 \\
\hline & & & 15 & 0,76 \\
\hline
\end{tabular}

\section{KESIMPULAN}

1. Terdapat 53 jenis tumbuhan bawah yang ditemukan di bawah tegakan kelapa sawit di Desa Kungkai Baru, Kecamatan Air Periukan, Kabupaten Seluma. Semakin tua umur tanaman kelapa sawit, semakin sedikit jumlah jenis tumbuhan bawah yang ditemukan di bawah tegakan kelapa sawit.

2. Dominasi jenis tumbuhan bawah dari famili Poaceae (suku padi-padian) terjadi pada seluruh umur tegakan kelapa sawit.

3. Biomassa tumbuhan bawah di antara tegakan kelapa sawit berbeda-beda menurut umur tegakan. Pada umur tanaman 2 tahun adalah 7.704,2 kg/ha, umur 7 tahun $5.267 \mathrm{~kg} / \mathrm{ha}$, dan 15 tahun $2.903,7 \mathrm{~kg} / \mathrm{ha}$. Daya tampung ternak pada masing-masing kebun adalah 2,01 $\mathrm{ST} / \mathrm{ha} /$ tahun (umur kebun kelapa sawit 2 tahun), 1,37 ST/ha/tahun (umur 7 tahun), dan 0,76 ST/ha/tahun (umur 15 tahun).

\section{DAFTAR PUSTAKA}

b.

Arsyad, M., Dharmono, Hardiansyah. 2011. Inventarisasi Jenis dan Dominasi Rumput (Famili Poaceae) di Kawasan Sumur Lumpur Barambai Desa Kolam Kanan Kecamatan Barambai Kabupaten
Barito Kuala. Jurnal Wahana-Bio 5:1-21.

Azhari, M.Q. 2017. Etnobotani dan Potensi Aren (Arenga pinnata Merr.) pada Masyarakat Suku Rejang Desa Air Merah, Rejang Lebong Bengkulu. Tesis. Institut Pertanian Bogor. $48 \mathrm{hlm}$.

Batubara. L.P. 2003. Potensi Integrasi Peternakan dengan Perkebunan Kelapa Sawit Sebagai Simpul Campbell, C. 2018. Poaceae - Plant Family. Encyclopedia Britannica. Sumber:

https://www.britannica.com/plant/Po aceae.

Daru, T.P., A. Yulianti, E. Widodo. 2014. Potensi Hijauan di Perkebunan Kelapa Sawit sebagai pakan Sapi Potong di Kabupaten Kutai Kertanegara. Pastura 3(2):94-98.

Direktorat Perbibitan Ternak Kementan. 2014. Pedoman Pembibitan Sapi Potong yang Baik. Direktorat Perbibitan Ternak. Jakarta. $30 \mathrm{hlm}$.

Ersyad, Z., Ardian, F. Silvina. 2017. Inventarisasi Gulma dan Seedbank pada Tanaman Kelapa Sawit (Elaeis guineensis Jacq.) Menghasilkan (TM) di Kebun Sei Galuh PT. Perkebunan Nusantara V Kampar Riau. JOM Faperta 4(2): 1-21. 
Farizaldi. 2011. Produktivitas Hijauan Makanan Ternak pada Lahan Perkebunan Kelapa Sawit berbagai Kelompok Umur di PTPN 6 Kabupaten Batanghari Provinsi Jambi. Jurnal Ilmiah Ilmu-ilmu Peternakan, 14(2):68-73.

Febriana, A. 2015. Carrying Capacity (Daya Tampung). Dalam Buku Pintar Peternakan (Jilid I), editor: R. Rawendra, K. Suharto, Sabir, Z. Mubarok, A. Lesmana, Hastutik, Rusmilawaty, Sjaifurahman, Afnita. Media Nusa Creative. Malang. 360 hlm. Agribisnis Ruminan. Wartazoa, 13(3):83-91.

Firison, J., A. Ishak. 2017. Pola Pemeliharaan Ternak Sapi Potong pada Wilayah Perkebunan Kelapa Sawit (Kasus di Kecamatan Air Periukan, Kabupaten Seluma, Provinsi Bengkulu). Prosiding Seminar Nasional Percepatan Alih Teknologi Pertanian mendukung Revitalisasi Pertanian dan Pembangunan Wilayah - Denpasar, 5 September 2017. Editor: I.G.N. Bidura, I.W. Rusastra, Rubiyo, I.M.R. Yasa, I.B.G.G. Suryawan, I.G.K.D. Arsana. Hlm. 1345-1354.

Gunawan, C. Talib. 2014. Potensi Pengembangan Bioindustri dalam Sistem Integrasi Sapi Sawit. Wartazoa 24(2):67-74.

Hutasoit, R., R. Rosartio, S. Elieser, Antonius, Syarifah. 2017. Vegetasi Alam di Perkebunan Sawit mendukung Produktivitas Sapi di Kabupaten Aceh Jaya. Di dalam Akselerasi Pengembangan Sapi Potong melalui Sistem Integrasi Tanaman Ternak: Sawit-Sapi. Editor: IW. Mathius, S. Bahri, Subandriyo. IPB Press. Bogor. Hlm. 47-62.

Indriyanto. 2012. Ekologi Hutan. Bumi Aksara. Jakarta. $224 \mathrm{hlm}$.

Ishak, A., J. Firison, Harwanto. 2017. Keberlanjutan Pola Penggaduhan Ternak Sapi Potong pada Tingkat
Kelompok Tani di Kabupaten Mukomuko, Provinsi Bengkulu. Prosiding Seminar Nasional Teknologi Peternakan dan Veteriner - Bogor, 8-9 Agustus 2017. Editor: W. Puastuti, S. Muharsini, I. Inounu, B. Tiesnamurti, E. Kusumaningtyas, E. Wina, T. Herawati, Hartati, R. Hutasoit. Hlm. 209-218.

Ismani, L., M. Lailati, Rustandi, D. Sunandar. 2015. Analisis Komposisi dan Keanekaragaman Tumbuhan di Gunung Dempo, Sumatera Selatan. Pros. Sem. Nas. Masy Biodiv. Indon. 1(6):1397-1402.

Kusuma, N.A., T. Suryani. 2017. Eksplorasi Tumbuhan Obat di Kawasan Hutan Alam Girimanik Setren Kecamatan Slogohimo Wonogiri. Proceeding Biology Education Conference 14(1):88-92.

Mathius, IW. 2008. Pengembangan Sapi Potong Berbasis Industri Kelapa Sawit. Pengembangan Inovasi Pertanian 1(2):206-224.

Purwantari, N.D., B. Tiesnamurti, Y. Adinata. 2015. Ketersediaan Sumber Hijauan di Bawah Perkebunan Kelapa Sawit untuk Penggembalaan Sapi. Wartazoa 25(1):47-54.

Prasetyo, H., S. Zaman. 2016. Pengendalian Gulma Perkebunan Kelapa Sawit (Elaeis guineensis Jacq.) di Perkebunan Padang Halaban, Sumatera Utara. Bul. Agrohorti 4(12):87-93.

Rad, J.E., M. Manthey, A. Mataji. 2009. Comparison of Plant Species Diversity with Different Plant Communities in Diciduous Forests. Int. J. Environ. Sci. Tech 6(3):389394.

Simangunsong, Y.P., S. Zaman, D. Guntoro. 2018. Manajemen Pengendalian Gulma Perkebunan Kelapa Sawit (Elaeis guineensis Jacq.): Analisis Faktor- faktor Penentu Dominansi Gulma di Kebun 
P-ISSN: 2302- 6715

E- ISSN: 2654-7732

Dolok Ilir, Sumatera Utara. Bul. Agrohorti, 6(2):198-205.

Syahputra, E., Sarbino, S. Dian. 2011.

Weeds Assessment di Perkebunan
Kelapa Sawit Lahan Gambut. J. Tek. Perkebunan \& PSDL 1:37-42.

Wiryono. 2009. Ekologi Hutan. UNIB Press. Bengkulu. 144 hlm. 